\title{
Discourse Analysis of General Muhammadu Buhari’s Official Acceptance Speech: A Systemic Functional Perspective
}

\author{
Innocent Sourou Koutchadé ${ }^{1}$ \\ ${ }^{1}$ Department of English, Faculty of Art and Humanities, University of Abomey-Calavi, Bénin Republic \\ Correspondence: Innocent Sourou Koutchadé, Department of English, University of Abomey-Calavi, 01 P. O. \\ BOX 526, Cotonou, Republic of Bénin. Tel: 229-9651-8643. E-mail: koutchade2@yahoo.fr
}

Received: June 27, 2015 Accepted: July 27, 2015 Online Published: September 29, 2015

doi:10.5539/ijel.v5n5p24 URL: http://dx.doi.org/10.5539/ijel.v5n5p24

\begin{abstract}
This paper attempts to analyze the acceptance speech of the Nigerian President-elect, General Buhari, through the framework of discourse analysis. Assuming that the aim of the President is to inform and convince his audience, the article adopts the systemic functional linguistic model to inquire into the language of the speech. Specifically, aspects of experiential meaning, realized through the transitivity patterns which focus on the different processes, participants and circumstances, and the interpersonal meaning, realized through modality, which includes modalization and modulation have been studied. The findings reveal that these linguistic features have made it easy to highlight not only Buhari's experience of the events he has described, but also his ideology, that is, his attitudes and judgments that are expressed to reinforce the persuasive strategies used in his speech.
\end{abstract}

Keywords: Discourse analysis, ideology, systemic functional linguistics, modality, political speech, transitivity

\section{Introduction}

Discourse analysis, a modern approach to text analysis, is a method for studying the ways that specific features of language contribute to the interpretation of texts in their various contexts (Barton, 2006). It facilitates the understanding of organization and functions of language in texts. In fact, texts analyses with a linguistic theory are the main concerns of Neo-Firthian linguists such as Halliday $(1978 ; 1985 ; 2002)$ and Hasan $(1985 / 1989)$. They have attempted to put together the linguistic interpretation of texts and discourse of various genres with the multiplicity of literary, sociopolitical and ideological perspectives that are loosely integrated under the name of semiotics (Halliday, 2002). As observed by Bloor and Bloor (2004), in order to explain how language works, contemporary linguists are often interested in the aspect of the language also referred to as discourse, considering that text is the data used as the object of the study.

The present work draws upon the discourse theory of systemic functional linguistics to analyze the political speech of the President-elect Buhari. Indeed, political speech is a special speech delivered by a politician on a particular occasion. It aims at convincing the audience regarding a political or social situation which is prevailing at a given period. Feng \& Liu (2010) say: "political speech is a kind of public speech given by authorities with political purposes that tries to influence a certain group of people" (p. 1). So, political speech is an aspect of political discourse, i.e., a discourse which is itself political, concerned with formal/informal political contexts and political actors and with politicians, political institutions, governments, political media, and political supporters operating in political environments to achieve political goals (Schiffrin, Tannen, \& Hamilton, 2001). The choice of this speech as corpus is prompted by the fact that it is delivered by the Nigerian President-elect, General Buhari, who defeated the outgoing President, Goodluck Jonathan, in the presidential election held on March 28th, 2015. This election has made history because it is the first time that a candidate of an opposition party has won the presidential election in Nigeria. Given that various crises (political, economic, and social) marked the end of President Jonathan government, the new Head of State appears, to most Nigerians, as an agent of hope restoration. As it is expected that the President-elect should address the people after being issued with his Certificate of Return, the one given to winners of elections in Nigeria (Elekwa, Eme, \& Uchechukwu, 2014), by the chairman of the Independent National Electoral Commission (INEC), Buhari has addressed Nigerians who are hungry for change, through an official acceptance speech. The importance of this speech, we think, can have a positive impact on them. Therefore, a study of the language of the speech from the linguistic point of view proves to be important. In addition, in order to provide a detailed analysis of linguistic features, we have 
limited the scope of the paper to this speech. Consequently, aspects of transitivity, "the particular grammatical facility used for capturing experience in language" (Simpson, 2004, p. 22) and modalities, "the degree of assurance or commitment with which a speaker vouches for a proposition" (Fowler, 1986, p. 57), have been investigated. The article accounts for the main features of systemic functional linguistics and draws upon them to analyze and decipher the language of Buhari.

\section{Theoretical Framework}

As said earlier, this study draws upon one of the most recent method of discourse analysis. It does not focus on the classical theories of pragmatics as developed by scholars such as Austin (1962), Searle (1969) and many others. Rather, it relies on Halliday's systemic functional linguistics because such a theory facilitates the understanding of the function and use of language in a cultural and situational context. As a matter of fact, systemic functional linguistics is an approach which considers language as a system of meanings. (Halliday, 1985). Indeed, when people use language, "their language acts produce or, more technically, construct meanings" (Bloor \& Bloor, 2004, p. 2, original emphasis). From this point of view, Halliday (1985) contends that language is structured to make three kinds of meanings simultaneously. These meanings, known as 'metafunctions', include:

-The interpersonal meaning: the meaning about the interaction between the speaker and the hearer (Halliday and Hasan, 1985/1989). In this particular type of metafunction, language is used to enable people to participate in communicative acts with other people, to take on roles and to express and understand feelings, attitudes and judgments (Bloor \& Bloor, 2004).

-The experiential meaning: the meaning about the representation of our experience in the real world. Here, language is used to organize, understand and express people's perception of the world and their own consciousness.

-The textual meaning: it is the one whose function is specifically that of creating text, of making the difference between language in the abstract and language in use (Halliday, 2002). This means that language is used to relate what is said (or written) to the rest of the text and to other linguistic events. As a matter of fact, these strands of meanings are all interwoven in the fabric of the discourse. This is why Halliday and Hasan (1985/1989) say that:

"The meanings are woven together in a very dense fabric in such a way that, to understand them, we do not look separately at its different parts; rather, we look at the whole thing simultaneously from a number of different angles, each perspective contributing towards the total interpretation. That is the essential nature of a functional approach" (p. 23).

Moreover, Halliday (1985) observes that these meanings are related to the context of situation and lexico-grammar. Indeed, the context of situation includes three variables known as register variables. These are: the field of discourse (what is going on), the tenor of discourse (who are taking part) and the mode of discourse (role assigned to language). The lexico-grammatical patterns realized by language are transitivity, mood and theme. Thus, for Halliday (1985), Halliday and Hasan (1985/1989), the field is expressed through the experiential meanings which are realized through the Transitivity patterns. As for the mode, it is expressed through the textual meanings; these meanings are realized through the Theme patterns. Finally, the tenor is expressed through the interpersonal meanings; these textual meanings are realized through the mood and modality. This paper is mainly concerned with aspects of experiential and interpersonal meanings. More specifically, it deals with transitivity and modality patterns.

\subsection{Transitivity}

As said earlier, transitivity is the realization of the experiential component. It refers to the way meanings are encoded in the clause and to the way different types of process are represented in language (Simpson, 2004). Halliday (1985) argues that transitivity specifies the different types of process that are organized in the language, and the structure by which they are expressed. For him, a process consists of three components which are: the process itself, the participants in the process, and the circumstances associated with the process.

There are six main processes:

-Material process: process of doing, particularly concrete or movement actions. There are two participants associated with this process; these are actor and goal.

-Mental process: process of sensing, with two participants which are senser and phenomenon.

-Behavioural process: process embodying physiological actions, with behaver as the main participant.

-Verbal process: process of verbal actions. It includes three main participants: sayer, receiver and verbiage. 
-Existential process: It represents experience by positioning that 'there was/is something'. This process has only one participant, the existent.

-Relational process: it includes attributive and identifying processes. In the attributive sub-type, an attribute is ascribed to some entity; either as a quality (intensive), as a circumstance or as a possession. It has two participants: the carrier and attribute. In the identifying mode, one entity is used to identify another; the relationship between them is one of token and value, of phenomenon and circumstance of time, or of owner and possession (Halliday, 1985).

The third component of clause as representation is circumstance. It is the name given to elements which carry a semantic load but are neither process nor participant. Circumstantial elements conflate with adjunct and the grammatical realization is adverb or prepositional phrase (Bloor \& Bloor, 2004). According to Halliday (1985), the main types of circumstantial elements are the following: extent and location in time and space, including abstract space; manner (means, quality and comparison); cause (reason, purpose and behalf); accompaniment (comitation, addition); matter (verbiage); role (guise, product).

\subsection{Modality}

Modality is an aspect of the interpersonal meaning. It is "the area of meaning that lies between yes and no- the intermediate ground between positive and negative polarity" (Halliday, 1985, p. 335). Simpson (2004, p. 123) contends that modality is that part of language which allows us to attach expressions of belief, attitude and obligation to what we say and write. It is the grammar of explicit comment, and it includes signals of the varying degrees of certainty we have about the propositions we express, and of the sorts of commitment or obligation that we attach to our utterances. This point of view is shared by Fowler (1986), who says "that modality is the grammar of explicit comment, the means by which people express their degree of commitment to the truth of the propositions they utter, and their views on the desiderability or otherwise of the state of affairs referred to" (p. 131).

As observed by Eggins (1994), Modality has two components which are: modalization and modulation. Indeed, modalization has to do with the expression of probability or frequency of proposition. It expresses two kinds of meanings which are: probability, where the speaker expresses judgments regarding the likelihood or probability of something happening or being, and usuality, where the speaker expresses judgments as to the frequency with which something happens or is. It is expressed through the choice of a finite modal operator like can, could, may, might, or mood adjunct of probability or certainty like possibly, I think, I'm sure, and finally through both modal Finite and a mood Adjunct. Modulation is the expression of obligation, necessity and inclination. It is used with finite verbal operators like should, must, need, shall, ought to, have to, etc. It is important to note that the use of modality has a significant impact on the tenor dimensions of a discourse. Through it, one can draw the power, contact and affective involvement of the interactants of the discourse.

\section{Data Analysis}

As said earlier, this study concerns the transitivity and modality analyses of a political speech. This is an acceptance speech issued on April 1st, 2015 by President-elect, Muhammadu Buhari, following his victory in Nigeria's Presidential elections. This speech (text) represents the data or corpus of the study. The transitivity analysis has been carried out with the framework of quantitative and qualitative approaches (Creswell, 2003; Osuala, 2007). This method aims at following the principles of discourse analysis. Barton (2006) says: "Discourse analysis can be practiced either quantitatively or qualitatively, or with an emphasis on linguistic structure or contextual function, although most discourse studies utilize a combined design of qualitative-quantitative and structural-functional methods and analyses" (p. 57). Indeed, features of transitivity have been identified, counted and analyzed. As regards modalities, no feature has been counted but aspects of modality (modalization and modulation) have been identified and studied qualitatively. Thus, in order to meet certain criteria in this analysis, clause, participant and circumstance identification has been carried out in the appendix.

\subsection{Transitivity Analysis}

As a matter of fact, transitivity deals with the semantics of the clause (Bloor \& Bloor, 2004). Basing on the identification implemented in the appendix, one can notice, clearly, the way processes are distributed in this text. In order to analyze these linguistic features, the process-types and participant configuration of ranking and embedded clauses are displayed in the table below: 
Table 1. Process-types statistics of the speech

\begin{tabular}{|c|c|c|}
\hline \multicolumn{2}{|l|}{ Process-types } & \multirow{2}{*}{$\begin{array}{l}\text { Number } \\
\text { Percentage }\end{array}$} \\
\hline & \\
\hline Materıal processes & & $\begin{array}{l}83 \\
37.22 \%\end{array}$ \\
\hline \multicolumn{2}{|l|}{ Mental processes } & 56 \\
\hline & & $25.11 \%$ \\
\hline \multicolumn{2}{|l|}{ Behavioral processes } & 20 \\
\hline & & $8.96 \%$ \\
\hline \multicolumn{2}{|l|}{ Verbal processes } & 23 \\
\hline & & $10.31 \%$ \\
\hline \multirow{2}{*}{\multicolumn{2}{|c|}{ Existential processes }} & 5 \\
\hline & & $2.24 \%$ \\
\hline \multirow{8}{*}{$\begin{array}{l}\text { Relational } \\
\text { Processes }\end{array}$} & Identifying & 23 \\
\hline & & $10.31 \%$ \\
\hline & Attributive & 09 \\
\hline & & $4.03 \%$ \\
\hline & Circumstantial & 4 \\
\hline & & $1.79 \%$ \\
\hline & Possessive & 00 \\
\hline & & $00 \%$ \\
\hline \multirow{2}{*}{\multicolumn{2}{|c|}{ Total }} & 223 \\
\hline & & $100 \%$ \\
\hline
\end{tabular}

As the above table shows, various processes are used in this speech. Indeed, out of a total of two hundred and twenty-three (223) processes, there are eighty-three (83) material processes, representing $37.22 \%$ of the total and fifty-six (56) mental processes, which stand for $25.11 \%$. This statistics shows that both material and mental processes are the most frequently used in the text, but material processes rank first whereas mental processes rank second. The predominance of these two processes means that the text is basically concerned with concrete and tangible actions, on the one hand, and also with mental reactions relating to thoughts, feelings and perceptions, on the other.

Relational processes rank third in this text [36/223 (16.14\%)], with a larger predominance of identifying processes [23 $(10.31 \%)]$. This shows that the speech is concerned with defining participants. In addition, attributive processes, although less numerous than identifying processes, are also used in this text [09 (04.03\%)], indicating that some participants, both animate and inanimate, are also described. However, very few proportions of circumstantial processes are used [04 (01.79\%)], whereas possessive processes are totally non-existent. Verbal processes rank fourth in this speech: [23/223 (10.31\%)]. This suggests that actions and events are described and performed verbally. Moreover, physiological actions are performed, which is demonstrated by the use of behavioural processes: [20/223 (08.96\%)]. Finally, existential processes are also used in the text [05/223 $(02.24 \%)$ ], showing that the speech also deals with actions that are taking place in really existing settings or/and beings.

The above statistics and its analysis give a broad picture of transitivity patterns in the speech. As a matter of fact, in order to answer the question: "who does what to whom, under what circumstances?", we have attempted to carry out a qualitative analysis of transitivity in the text. This consists in focusing on the linguistic features that are realized in some prominent passages (see the appendix) of the speech. Here is an example:

1-I $(\mathrm{Cr})$ am (Pi) immensely $(\mathrm{Cm})$ grateful (At) to God $(\mathrm{Cl})$ for this day and for this hour $(\mathrm{Cl})$. 2- $\mathrm{I}(\mathrm{Cr})$ feel(Pi) truly $(\mathrm{Cm})$ honoured and humbled(At) 3-that the Nigerian people(A) have so clearly $(\mathrm{Cm})$ chosen(Pm) me $(\mathrm{G})$ [[to lead(Pme) them $(\mathrm{Ph})]]$. 4-The official announcement from $\operatorname{INEC}(\mathrm{T})$ was(Pi) the moment(V) 5-the vast majority of Nigerians(S) had hoped(Pme) 6-and been waiting for(Pm). 7-Today $(\mathrm{Cl})$, history $(\mathrm{Ph})$ has been made(Pme), 8-and change(A) has finally come(Pm). 9-Your votes (A) have changed (Pm) our national destiny $(\mathrm{G})$ for the good of all Nigerians $(\mathrm{Cl})$. 10-INEC(Sy) has announced (Pv) 11-that I, Muhammadu Buhari,(T) shall be(Pi) your next president(V). 12-My team and $\mathrm{I}(\mathrm{A})$ shall faithfully $(\mathrm{Cm})$ serve(Pm) you(G). 13-There shall no longer be $(\mathrm{Pe})$ a ruling $\operatorname{party}(\mathrm{X})$ again $(\mathrm{Cl})$ : 14-APC $(\mathrm{T})$ will be(Pi) your governing party $(\mathrm{V})$. 15-We(A) shall faithfully $(\mathrm{Cm})$ serve $(\mathrm{Pm})$ you $(\mathrm{G})$. 16-We(A) shall never $(\mathrm{Cm})$ rule(Pm) over the people $(\mathrm{Cl})$ 17-as if they $(\mathrm{Cr})$ were $(\mathrm{Pi})$ subservient(At) to government $(\mathrm{Cl})$. 
From the above passage, it appears that various processes are used by General Buhari. Indeed, material processes occur in clauses $(3,6,8,9,12,15,16)$. In (3), the actor role is played by "the Nigerian people", mainly those who have cast their vote for the President-elect Buhari. This process is accompanied by the circumstance of manner "clearly" to show that he has not been elected on the basis of the ballot rigging. The same actor role is synonymous with those in (6) and (9) as these actor participants refer to the Nigerians. In $(12,15,16)$, the actor roles are played by Buhari and his team, anaphorically referred to as "we" in (15) and (16). These three processes are projected into the future to express the challenges to be taken up to maintain the changes caused by Buhari's election. In addition, one can notice that all these processes, except the one of clause (8), are transitive material processes in which the goal is "me" (Buhari) in (3), "the moment" in (6), "our national destiny" in (9), "you" (the Nigerian people) in (12) and (15). In (15), the circumstantial element "faithfully" is used to show the way the country will be governed. The use of these processes surely confirms the fact that concrete actions and events have been portrayed by the President-elect Buhari.

Mental processes are used in $(3,5,7)$. In $(3)$, it occurs in an embedded clause to show that the whole Nigerians will, henceforth, be governed by Buhari. Clause (5) displays "the vast "majority of Nigerians" as senser. They are expecting that new change to come. Finally, in clause (7), the mental process is used in the passive form to describe his victory which is considered as the memorable event that has been caused by Nigerians, as described in (3). As far as relational processes are concerned, they are used in $(1,2,4,11,14,17)$. Attributive processes occur in $(1,2,17)$. In (1) and (2), the carrier role is played by "I" and refers back to Buhari who is expressing his gratitude to the people of Nigeria. Each of these attributive elements are followed by the circumstantial of manner: "immensely" in (1) and "truly" in (2). The attributive used in (17) bears "they" (that is the citizens) as a carrier. As for the defining processes of $(4,11,14)$, we notice that the carrier role, in clause (4), is played by the nominalized element "the official announcement from INEC" whereas the value role is "moment". In (11), Buhari is identified as the next president of Nigeria, whereas in (14), "APC" (All People Congress), the opposition party is valued as the "next governing party". This clause expresses part of Buhari's beliefs and perspectives. Here, the existent "the ruling party" in the only existential clause (13) of the passage is shifted to "your governing party" in the clause (13).

Another striking passage to be analyzed includes the following:

68-But despite the rancor of the elections $(\mathrm{Ca}), \mathrm{I}(\mathrm{S})$ extend(Pme) a hand of friendship and conciliation $(\mathrm{Ph})$ to President Jonathan and his team $(\mathrm{Cl})$. 69-I(S) hereby wish(Pme) [[to state(Pv)]] 70-that $\mathrm{I}(\mathrm{S})$ harbor(Pme) no ill will( $\mathrm{Ph})$ against anyone $(\mathrm{Cl})$. 71-Let me(Sy) state $(\mathbf{P v})$ clearly $(\mathrm{Cl})$ 72-that President Jonathan $(\mathrm{S})$ has nothing to fear(Pme) from me $(\mathrm{Cl})$. 73-Although we(S) may not agree on (Pme) the methods $(\mathrm{Ph})[[$ of governing $(\mathbf{P m e})$ the nation $(\mathrm{Ph})]$ ], 74-he $(\mathrm{T})$ is $(\mathrm{Pi})$ a great Nigerian and still our president $(\mathrm{V})$. $75-\mathrm{He}(\mathrm{S})$ deserves $(\mathbf{P m e})$ our support and permanent $\operatorname{respect}(\mathrm{Ph})$ [[by virtue of the office $(\mathrm{Cl})$ he(A) has held(Pm)]]. 76-This(T) is(Pi) 77-how an honorable nation $(\mathrm{Bh})$ treats $(\mathbf{P b})$ its servants(Bv) 78 -and conducts(Pme) its affairs $(\mathrm{Ph})$; 79-and this( $\mathrm{T})$ is $(\mathbf{P i})$ 80-how $(\mathrm{V})$ Nigeria(Cr) should be(Pi). 81- $\mathrm{I}(\mathrm{Bh})$ look forward(Pme) $[$ to meeting with(Pb) President Jonathan $(\mathrm{Bv})$ in the days $(\mathrm{Cl})[[$ to $\operatorname{come}(\mathbf{P m}) / /$ to $\operatorname{discuss}(\mathbf{P v})]]$ 82-how our teams(A) can make(Pm) the transition of administrations $(\mathrm{G})$ as efficient as possible $(\mathrm{Cm})$.

From the above passage, one can notice the distribution of processes such as: mental in $(68,69,70,72,73,75$, $78,81)$. Indeed, those in $(68,69,70,72,75)$ are all processes of affection and the sensors are all conscious beings: "I" (the president-elect) in $(68,69,70)$, President Jonathan, in (72), anaphorically referred to as "he" in (75). The use of phenomena such as "a hand of friendship in (69) "no ill will" in (70), and "our support and permanent respect" in (75) and the circumstantial elements "to President Jonathan and his team" reveals, clearly, part of Buhari's beliefs and commitments: the desire to reconcile the people of Nigeria. Mental processes of perception are used in $(73,78)$, with "we" (referring to President Jonathan and Buhari) as the senser in (73) and "an honourable nation" in (78). The only process of perception is used in (81) and its senser is "I" (Buhari). These mental processes clarify the fact, in his text, Buhari describes conscious participants, including himself, who feel, see and think.

As for behavioural processes, they occur in $(77,81)$, with "an honourable nation" as the behaver in (77) and "Nigeria" in (81). These participants refer to people (conscious-beings) who have shown their physiological attitudes towards the political events in Nigeria. Verbal actions are used in $(69,71,81)$. In these clauses, the senser role is played by Buhari. Most of them are used in emdedded clauses. They are not meant to show the lack of seriousness with which Buhari is speaking but they simply express the respect and admiration the latter has for President Jonathan. Relational processes are used in $(74,76,79)$. All of them bear defining processes. Indeed, in (74), "he" (President Jonathan) is defined as a great Nigerian because he has accepted his defeat. Clauses (76, 79) have "this" as token but the value roles are played by the following dependent clauses: "how an honourable 
nation treats its servant" and "how Nigeria should be". Buhari's appeal to his nation is that every Nigerian citizen should smoke the peace pipe and secure the national unity. Finally, clauses $(75,81,82)$ display material processes which portray actions and events in the passage. Moreover, one important passage to be taken for granted in this analysis includes the following:

108-No doubt, this nation $(\mathrm{Be})$ has suffered $(\mathrm{Pb})$ greatly $(\mathrm{Cm})$ in the recent past $(\mathrm{Cl})$, 109-and its staying power(G) has been tested $(\mathbf{P m})$ to its limits $(\mathrm{Cx})$ by crises(A), [[chief among which $(\mathrm{V})$ is $(\mathbf{P i})$ insurgency of the Boko $\operatorname{Haram}(\mathrm{T})]]$. 110-There is(Px) no $\operatorname{doubt}(\mathrm{X})$ 111-that $[[$ in $\operatorname{tackling}(\mathbf{P m})$ the insurgency(G)]] we(A) have(Pm) a tough and urgent job(Pd)[[to do(Pm)]]. 112-But $\mathrm{I}(\mathrm{S})$ assure $(\mathrm{Pv})$ you $(\mathrm{Ph})$ 113-that Boko Haram $(\mathrm{S})$ will soon know(Pme) the strength of our collective will and commitment $(\mathrm{Ph})[[$ to $\operatorname{rid}(\mathbf{P m})$ this nation of terror(G),// and bring back $(\mathrm{Pm})$ peace and normalcy $(\mathrm{G})$ to all the affected $\operatorname{areas}(\mathrm{Cl})]]$. 114-We(A) shall spare(Pm) no effort $(\mathrm{G})$ 115-until we(A) defeat (Pm) terrorism(G). 116-Furthermore, we(A) shall strongly battle(Pm) another form of evil(G) $[[$ that $(\mathrm{Cr})$ is $(\mathbf{P i})$ even worse than terrorism(At) - the evil of corruption. 117-Corruption(A) attacks(Pm) 118-and seeks(Pb) [[to destroy $(\mathbf{P m})$ our national institutions and character $(\mathrm{G})]]$. 119-[[By misdirecting $(\mathbf{P m})$ into selfish hands $(\mathrm{Cl})$ funds $(\mathrm{G})[[$ intended for $(\mathbf{P m e})$ the public purpose $(\mathrm{Ph})]]]]$, corruption(A) distorts $(\mathbf{P m})$ the economy $(G)$ 120-and worsens $(\mathbf{P m})$ income inequality $(\mathrm{G})$. 121-It(A) creates(Pm) a class of unjustly-enriched people $(G)$. 122-Such an illegal yet powerful force soon $(A)$ comes $(\mathbf{P m})[[$ to undermine(Pm) democracy $(G)$ 123-because its conspirators(A) have amassed(Pm) so much money(G) 124-that they(S) believe(Pme) 125-they(A) can buy(Pm) government(G). 126-We(A) shall end(Pm) this threat(G) to our economic development and democratic survival(Cl). 127-I(Sy) repeat(Pv) 128-that corruption( $\mathrm{Ph})$ will not be tolerated(Pme) by this administration(S); 129-and it (S)shall no longer be allowed(Pme) [[to stand(Pm)]] 130-as if it $(\mathrm{T})$ is $(\mathbf{P i})$ a respected monument $(\mathrm{V})$ in this nation $(\mathrm{Cl})$.

From the above excerpt, we notice that behavioural processes are used in $(108,118)$. In (108), the behaver is "this nation", indirectly referred to as "the people of Nigeria", conscious being who are displaying their physiological and psychological behavior. In addition, the first behavioural process is followed by circumstances of manner "greatly" and location "in the recent past" to point out the way and moment Nigeria has experienced some difficulties. The second clause displays "Corruption" as behaver. Here, "corruption" is ascribed to human characteristics in (118) because, human-being are the main actors. Material processes are predominant in this passage. They occur in $(109,111,113,115,116,117,118,119,120,121,122,123,125,126,129)$. One can notice that some processes in the speech are in the passive form, e.g: (109) while the others are in the active voice. As observed by Bloor \& Bloor (2004), "the choice between active and passive voice is significant [. . .] since the item which is Complement in the active is Subject in the corresponding passive, but the items retain the same functions of Actor or Goal regardless of voice" (p.112). In addition, almost all the processes are transitive. The intransitive processes occur only in $(122,129)$. In fact, "we" as actor in $(111,114,115,117)$ shows not only Buhari's commitment to act directly against Boko Haram and corruption, but it also shows that he wants to raise the awareness of the Nigerians on the fact that their cooperation should facilitate the implementation of his decision-making. Mental processes are used in $(113,119,124,128,129)$. The senser in (113) is "Boko Haram" with its phenomenon: "the strength of our collective will and commitment", indicating Buhari's strong desire, in collaboration with the armed forces, to totally eradicate terrorism in Nigeria. Likewise, the senser in (119) is "funds" and the phenomenon is "the public purpose" whereas in (124) "they" is the senser and the phenomenon is projected to the next clause "they can buy the government". This shows the extent to which some Nigerians, after destroying the country's economy with their attitude of corruption, give the impression that with their money, they are above the law. The other processes are used in the passive form by the President-elect to show how some corrupted Nigerians tend to minimize the negative effects of corruption. Actually, the senser role in the two clauses $(128,129)$ is "this administration" and the senser is "corruption", a proof that Buhari's administration will cherish the sense of good governance. The verbal processes used in $(112,127)$ have "I" as sayer in (112) and (127). However, in (112) the verbiage is "you" (Nigerians) whereas in (127) the verbiage is projected to (128): "that corruption will not be tolerated by this administration", to show the commitment of the new president to eradicate corruption. The transitivity analysis being carried out, we now focus on modality analysis in the next sub-section.

\subsection{Modality Analysis}

Taking into account the different identified clauses in the appendix, we have attempted to point out some instances of modality in the text. Each modality-type and its nature have been recapitulated in the table 2 below: 
Table 2. Modality in the speech

\begin{tabular}{lll}
\hline Clause number & Modality elements & Nature \\
\hline$(1)$ & immensely & modalizer \\
modalizer \\
$(2,91)$ & Truly & modalizer \\
modulator \\
$(14,15)$ & Faithfully & modulator \\
$(11,12,13,15,16,45,47,48,54,55,126,138,140,143)$ & Shall & modulator \\
$(49,51)$ & shall be able to & modalizer \\
$(14,37,38,96,98,106,107,113,128,132,134,137,153)$ & Will & modalizer \\
$(16,37,65,139)$ & Never & modulator \\
$(71,91)$ & Clearly & modalizer \\
$(129)$ & I shall be allowed to & modalizer \\
$(160)$ & have been allowed to & modalizer \\
$(42,95,97,112)$ & I assure you that & modalizer \\
$(97)$ & I want to assure you & modulator \\
$(65,151)$ & Would & modalizer \\
$(40,94)$ & Must & modalizer \\
$(82,125)$ & Can & modulator \\
$(25,73)$ & May & modalizer \\
$(80)$ & Should & modalizer \\
$(108)$ & Greatly & modalizer \\
$(108)$ & no doubt & Strongly \\
$(116)$ & & \\
\hline
\end{tabular}

It can be noticed that this text displays a high proportion of modulation. This means that in his speech, Buhari modulates more than he modalizes. The two modal verbal operators which express the predominance of modulation are: "shall" and "will". According to Quirk and Greenbaum (1979), both "shall" and "will" are used to express willingness, intention and insistence. Eggins (1994) shares this point of view; she says: "the Finite will or shall express a meaning of willingness, i.e. positive inclination viewed from the speaker's perspective" (p.186). In his speech, one can notice that Buhari modulates with the finite verbal operator "shall" in clauses (11, $12,13,15,16,45,47,48,54,55,126,138,140,143)$. In (11), it shows that Nigerians cannot but accept Buhari as their new Head of State and also points out the authoritarian tone of INEC, a system responsible for the organization of elections in Nigeria. In $(12,13,15,16)$, "shall" expresses Buhari and his team's perspectives, i.e., APC, an opposition party has become a governing party. Part of the ideological perspective of Buhari is that there will be a change in the way the country will be governed. For him, there shall be a true expression of democracy, i.e. the government of people by the people for the people. This is shown in his speech through the use of the subject "my team and I" in (12), anaphorically referred to as "we" in $(15,16)$. The modulator "shall" is also used by Buhari in $(45,47,48)$ to advocate the sense of fairness, equality, justice and rule of law. These principles are reinforced by freedom of movement, thought and speech as expressed by the modulator "shall" in $(49,51)$ on the one hand, as well as in $(54,55)$, on the other. In $(126)$, "shall" is used to emphasize Buhari's insistence and commitment to reinforce democracy and economic recovery. Finally, in $(138,140,143)$, Buhari has used the modulation "shall" to show his determination to guarantee good governance that will enable him to live up to Nigerians' expectations.

Likewise, "will" is used to modulate in $(14,37,38,96,98,106,107,113,128,132,134,137,153)$. In (14), apart from functioning as a future- tense modal, "will" is used by Buhari to insist on the nature of the party that will be leading Nigeria. In (37), it is used with "never" to show the determination of the President-elect to reinforce democracy as stated in $(38,106,107)$ and the frequency within which he will honour the memory of those who lost their lives in the process of democracy restoration in his country, Nigeria. Buhari's determination to bring Nigeria to rank among the best nations that are ready to take up the gauntlet as regards the matters of collective concern such as terrorism, climate change, drugs, poverty, etc. is expressed by the modulator "will" in $(96,98)$. His ideological stance is also disclosed in (113). He uses the modulator "will" to show his intention and insistence to guarantee the supremacy of the Nigerian army and their ability to eradicate Boko Haram in Nigeria. Moreover, his willingness to eradicate corruption is revealed with the use of finite modal operator "will" in (128), whereas in $(132,134,137)$, "will" is used to point out that Nigeria can be well-governed only if he can rely on the good collaboration of each citizen of the country. This is why he uses "will" in (153) to point out his intention to satisfy everybody with his governance. 
Apart from these finite modal operators that have been used intensively in the text, other aspects of modulation have also been identified. Indeed, "must" in $(40,94)$ is used to add obligation and forcefulness to Buhari's speech. In (40), it expresses obligation and necessity (Quirk \& Greenbaum, 1979). As a matter of fact, Buhari is urging his people to forget about their past differences and focus on the future that will be improved by his governance. The obligation of a formal appreciation towards the civil society and the international observers is expressed in (94). Similarly, strong modulator "should" is used in (80) to express the necessity for all Nigerians to acknowledge the patriotic behavior of President Goodluck Jonathan, for having accepted his defeat. Finally, the modulator "shall be able to" in $(49,51)$ is used by Buhari to show his strong desire to guarantee the right of access, individual freedom and freedom of thought. These finite modal operators are meant to express subjective meanings. They represent the speaker's assertion of the obligations inherent in the situation (Halliday, 2002). Eggins (1994) observes that the preference for subjective expression of modality indicates that the arguability of proposition will center around the degree of modality (high, median, low).

Moreover, another aspect of modality that operates in this speech is modalization. In this text, features of modalization are realized through modal verbal operators and mood adjuncts. The modal verbal operators occurring in this text include: "would" in $(65,151)$. In $(65)$, it is used to express Buhari's insistence regarding his capability to govern the Nigerian country, whereas in (151), it denotes his request for the acceptance of progressive change. Likewise, the finite modal operator "can" in (82) is used to express the possibility of a transition period between President Jonathan's administration and that of Buhari, whereas "can" in (125) expresses not only a theoretical ability of some corrupted politicians to influence people's votes with their money, but it also shows Buhari's indignation about corruption. In addition, the finite modal "may" denotes probability in (25) and (73). Similarly, its equivalent is used in (160) to express Buhari's judgment about the likelihood of transparent presidential election.

It is important to note that instances of high modalizers occur in $(42,95,97,112)$. As observed by Eggins (1994, p. 182), the use of "I assure...that" "involves grammatical metaphor: a clause expressing the modulation is appended to the main clause and such a structure allows the speaker to hide behind an ostensibly objective formulation". Actually, these assertive forms of modalization express Buhari's determination and insistence to tell all Nigerians that a new form of governance that will meet their expectations will be taking place.

Similarly, this text displays some instances of modal adjuncts, such as: "immensely" in (1), "truly" in $(2,91)$, "faithfully" in $(14,15)$, clearly in $(71,91)$, "greatly" in (108), "strongly" in (116). These high modalizations are used by Buhari to express intensification regarding the different issues, previously discussed above, which have been addressed by the latter. In addition, "never" is used in $(16,37,65,139)$ to express the degree of usuality. Here, Buhari has pointed out his judgments as to the frequency with which the actions described happen or are (Eggins, 1994). Finally, "no doubt", an evaluate adjunct, is used in (108) to comment on what the Nigerian nation has gone through in terms of difficulties including terrorism, corruption, financial fraud, communicable diseases, climate change, etc. On the whole, through the two grammatical sub-systems of modalization and modulation brought together under the label modality, Buhari has tempered the exchange with Nigerians by expressing degree of either probability/usuality or obligation/inclination (Eggins, 1994).

\section{Discussion of Findings and Conclusion}

The findings reveal that transitivity and modality analyses have proved to be useful for a thorough investigation of the speech under analysis. As a matter of fact, the study of transitivity has shown how Buhari has expressed, through his idiolect, his own experience of the world-view. As Halliday (2002) puts it,

language serves for the expression of the content: it has a representational, or, as I would prefer to call it, an ideational function...the speaker or writer embodies in language his experience of the phenomena of the real world; and this includes his experience of the internal world of his own consciousness: his reactions, cognitions, and perceptions, and his linguistic acts of speaking and understanding (pp. 90-91), original emphasis.

Through the analysis carried out in the above section, one can notice that language has contributed to revealing Buhari's experience of the world-view. As a matter of fact, Buhari has made use of an important number of material processes [83 (37.22\%)], mental processes [56 (25.11\%)], verbal processes [23 (10.31\%)], relational processes [36 (16.14\%)], and behavioral processes [20(08.96\%)] to point out how the field of situation is made in the text. This relates to what language is used to talk about. In addition, from the transitivity analysis, one can draw the ideological standpoint of the President-elect. As observed by Eggins (1994), the impact of ideology on field relates to how the text encodes such experiential meanings as: who initiates, what kinds of actions/events, who responds to those actions and how. Indeed, as can be deduced from the analysis, language is used here to deliver speech, a political discourse by Buhari who, in his address as the President-elect, has expressed his 
appreciation towards his team, INEC, International organizations, the observers and the whole people of Nigeria. Apart from accounting for the events surrounding the elections, he focuses on the different challenges to be taken up. These include guaranteeing good governance and national unity, improving the national economy, overcoming crises such as terrorism, corruption, etc. So, Buhari initiates his address to calm his people/ audience by promising to bring change and hope that most of the Nigerians are waiting for.

As regards modality, it is noticed that Buhari modulates, in his speech, more than he modalizes. Specifically, the findings reveal that the modal operators "shall" and "will", and more specifically the use of "we shall..." not only express his obligations and inclinations to satisfy his audience, but it is also a way of showing the same audience that his commitment is to guarantee good governance. This is why he is urging himself and his team to work hard in order to satisfy the people of Nigeria. This aspect of modality is also reinforced by modalization which is used to express his judgments about the certainty, likelihood, and frequency through which the political situation and the strong desire manifested by Buhari to bring hope to Nigerians' need are addressed. Actually, the analyses of the modality-types have enabled us to find out how an aspect of interpersonal meaning is realized and it also enables me to draw the tenor and part of Buhari's ideological perspectives. Eggins (1994) says that the impact of ideology on tenor relates to how the writer/speaker relates to the reader/hearer; how typical/likely/intense experiences are; who the core participants being argued about are, etc. From this, we can deduce that, although Buhari is henceforth the President of Nigeria, he does not speak with an authoritarian tone, which means that there seems to be an equal power between his audience and himself. The use of evaluative adjuncts such as "immensely" in (1), "truly" in $(2,91)$, "faithfully" in $(14,15)$, clearly in $(71,91)$, "greatly" in (108), "strongly" in (116) and the high modalizers such as "I assure you" together with the modulator "must" "should", show that Buhari considers his people as having more power than himself. He wants to show the whole country that he will behave as if he were their servant. This proves that the affective involvement between his audience and himself is high. He has tried to be so close to them. Moreover, focusing on some aspects of his ideological standing, we can say that friendly tenor has been adopted, and Buhari makes sure he organizes his speech in such a way as to attract the attention of his listeners as he has succeeded in touching their feelings. The speech/text is then an appeal to all Nigerians to make sure and be aware that they can forget about the past experiences to focus on the hope in the future.

Finally, this study has attempted to use an aspect of discourse analysis, viz: systemic functional linguistics, to investigate Buhari's idiolect in his speech. The transitivity and modality analysis has shown how he has played the role of information deliverer to relate political events and issues the whole Nigeria is aware of, on the one hand, and also shown his attitudes and opinions regarding these events, on the other. Basing on the cultural and situational context (Halliday, 1978, 1985; Eggins 1994), one can observe that the attention of any conscious politician in Nigeria must be drawn to the situations that the country has been going through so far, which are exemplified by crises including political unrest, economic crisis, socio-religious afflictions and, mainly, terrorism. As observed by Thurston (2015), the new President "will lead Nigeria through a turbulent period in which he will be pressured by Nigerians and the international community to end the Boko Haram crisis, redouble Nigeria's leadership in African affairs, and translate the country's economic growth into broad-based prosperity" (p.16) . In addition, since the advent of Democracy in 1999, it is the first time a candidate of the opposition party, All Progressives Congress (APC), has been elected President in Nigeria. This is why Buhari, as the President-elect of the opposition party, cannot but deliver a speech which, not only can persuade his people and the whole nation but it must also and mainly bring hope within the people who simply need to alleviate their sufferings and witness good governance and peace in their country. The analysis has, thus, shown that Buhari is a wise speaker who has tried, through his speech, to tell Nigerians to remain hopeful about the future of their country.

\section{References}

Austin, J. L. (1962). How to do Things with Words. Oxford: Clarendon Press.

Barton, E. (2006). Linguistic Discourse Analysis: How the Language in Texts Works. In C. Bazerman \& P. A. Prior (Eds.), What Writing Does and How it Does it: An Introduction to Analyzing Texts and Textual Practices. (pp. 57-82). London: Elbaum.

Bloor, T., \& Bloor, M. (2004). The Functional Analysis of English: a Hallidayan Approach (2nd ed.). London: Hodder Education.

Buhari's Acceptance Speech. (2015, April 1). Vanguard. Retrieved from http:/www.vanguardngr.com./2014/04/buhari-acceptance-speech 
Creswell, J. W. (2003). Research Design: Qualitative, Quantitative, and Mixed Methods Approaches (2nd ed.). London: Sage Publications, Inc.

Eggins, S. (1994). An Introduction to Systemic Functional Linguistics. London: Pinter Publishers.

Elekwa, N. N., Eme, O. I., \& Uchechukwu, A. N. (2014). Ethics, Accountability and Transparency in the Conduct of Election in Nigeria. Arabian Journal of Business and Management Review (OMAN Chapter), 4(3), 21-30.

Fairclough, N. (1989). Language and Power. London: Longman.

Feng, H., \& Liu, Y. (2010). Analysis of Interpersonal Meaning in Public Speeches-A Case Study of Obama's Speeches. Journal of Language Teaching and Research, 1(6), 825-829. http://dx.doi.org/10.4304/j1tr.1.6

Fowler, R. (1986). Linguistic Criticism. Oxford: Oxford University Press.

Halliday, M. A. K. (1973). Explorations in the Functions of Language. London: Edward Arnold.

Halliday, M. A. K. (1978). Language as a Social-Semiotic: The Social Interpretation of Language and Meaning. London: Edward Arnold.

Halliday, M. A. K. (1985). Introduction to Functional Grammar. London: Edward Arnold.

Halliday, M. A. K. (2002). Linguistic Studies of Text and Discourse. Collected Works of Michael Halliday, Vol. 2. Edited by J. J. Webster. London and New York: Continuum.

Halliday, M. A. K., \& Hasan, R. (1976). Cohesion in English. London: Longman Group.

Halliday, M. A. K., \& Hasan, R. (1985). Language, Context, and Text: Aspects of Language in a Social-semiotic Perspective. Oxford: Oxford University Press.

Halliday, M. A. K., \& Matthiessen, C. (2004). An Introduction to functional grammar (3rd ed.). London: Edward Arnold.

Hasan, R. (1985/1989). Linguistics, Language and Verbal Art. Oxford: Oxford University Press.

Koussouhon, A. L., \& Dossoumou, A. M. (2014). Lexico-Grammatical Analysis of Yellow-Yellow by Kaine Agary with a Focus on Experiential and Textual Meanings. Mediterranean Journal of Social Sciences, 5(23), 2430-2436. http://dx.doi.org/10.5901/mjss.2014.v5n23p2430

Osuala, E. C. (2007). Introduction to Research Methodology. Onitsha: Africana-First Publisher Limited.

Quirk, R., \& Greenbaum, S. (1979). A University Grammar of English. London: Longman Group Limited.

Searle, J. R. (1969). Speech Acts. Cambridge: Cambridge University Press. http://dx.doi.org/10.1017/CBO9781139173438

Simpson, P. (2004). Stylistics: A Resource Book for Students. London: Routledge.

Thurston, A. (2015). Background to Nigeria's 2015 Elections. Retrieved from http://csis.org./files/publication/150126_Thurston_NigeriaElections_Web.pdf

Wilson, J. (2001). Political discourse. In D. Schiffrin, D. Tannen, \& H. E. Hamilton (Eds.), The Handbook of Discourse Analysis (pp. 398-415). Oxford: Blackwell Publishers Ltd.

\section{Appendix A}

\section{Clause, Process, Participant and Circumstance Identification}

This speech (text) under analysis has been divided into clauses, with embedded clauses [[shown within double brackets]]. Double slashes lines // indicate clause boundaries with embedded clauses (Eggins, 1994). Thus, the identification of processes in both ranking (non-embedded) and embedded clauses is carried out under the following keys:

\section{Keys:}

$\mathbf{P}=$ process (in bold), $\mathrm{Pm}=$ material, $\mathrm{Pme}=$ mental, $\mathrm{Pb}=$ behavioural, $\mathrm{Pv}=$ verbal, $\mathrm{Pe}=$ existential, $\mathrm{P}=$ intensive, $\mathrm{Pcc}=$ circumstancial, $\mathrm{Pp}=$ possessive, $\mathrm{Pc}=$ causative $\mathrm{A}=$ Actor, $\mathrm{G}=$ Goal, $\mathrm{B}=$ Beneficiary, $\mathrm{R}=$ Range $\mathrm{S}=$ Senser, $\mathrm{Ph}=$ Phenomenon, $\mathrm{Sy}=$ Sayer, $\mathrm{Rv}=$ Receiver, $\mathrm{Vb}=$ Verbiage $\mathrm{Be}=$ Behaver, $\mathrm{Bh}=$ Behaviour, $\mathrm{X}=$ Existent $\mathrm{T}=$ Token, $\mathrm{V}=$ Value, $\mathrm{Cr}=$ Carrier, $\mathrm{At}=\mathrm{Attribute} \mathrm{Pr}=$ possessor, $\mathrm{Pd}=$ possessed $\mathrm{C}=$ Circumstance, $\mathrm{Cl}=$ location, $\mathrm{Cx}=$ extent, $\mathrm{Cm}=$ manner, $\mathrm{Cc}=$ cause, $\mathrm{Ca}=$ accompaniement, $\mathrm{Ct}=$ matter, $\mathrm{Co}=$ role. 


\section{Speech}

1-I (Cr) am (Pi) immensely $(\mathrm{Cm})$ grateful $(\mathrm{At})$ to $\mathrm{God}(\mathrm{Cl})$ for this day and for this hour $(\mathrm{Cc})$. 2-I $(\mathrm{Cr})$ feel(Pi) truly honoured and humbled(At) 3-that the Nigerian people(A) have so clearly $(\mathrm{Cm})$ chosen(Pm) me [[to lead(Pme) them $(\mathrm{Ph})]$ ]. 4-The official announcement from $\mathrm{INEC}(\mathrm{T})$ was $(\mathbf{P i})$ the moment(V) 5-the vast majority of Nigerians(S) had hoped(Pme) 6-and been waiting for $(\mathbf{P m})$. 7-Today $(\mathrm{Cl})$, history $(\mathrm{Ph})$ has been made(Pme), 8-and change(A) has finally come(Pm). 9-Your votes (A) have changed (Pm) our national destiny(G) for the good of all Nigerians $(\mathrm{Cc})$.

10-INEC(Sy) has announced (Pv) 11-that I, Muhammadu Buhari,(T) shall be(Pi) your next president(V). 12-My team and $I(A)$ shall faithfully $(\mathrm{Cm})$ serve(Pm) you(G). 13-There shall no longer be (Pe) a ruling party $(X)$ again $(\mathrm{Cl})$ : 14-APC(T) will be(Pi) your governing party(V). 15-We(A) shall faithfully $(\mathrm{Cm})$ serve(Pm) you(G). 16-We(A) shall never $(\mathrm{Cm})$ rule(Pm) over the people $(\mathrm{Cl})$ 17-as if they $(\mathrm{Cr})$ were(Pi) subservient(At) to government $(\mathrm{Cl})$.

18-Our long night (A) has passed(Pm) 19-and the daylight of new democratic governance (A) has broken (Pm) across the land $(\mathrm{Cl})$. 20-This $(\mathrm{T})$ therefore is $\operatorname{not}(\mathbf{P i})$ a victory $(\mathrm{V})$ for one man or even one $\operatorname{party}(\mathrm{Cl})$. 21-It(T) is $(\mathbf{P i})$ a victory $(\mathrm{V})$ for Nigeria and for all Nigerians $(\mathrm{Cl})$. 22-Millions of you(A) have worked $(\mathbf{P m})$ for this day $(\mathrm{Cc})$. 23-So many(A) have risked(Pm) life and livelihood'G); 24-and others(A) have $\operatorname{died}(\mathbf{P m}) \mathbf{2 5}$-that we(Be) may witness $(\mathrm{Pb})$ this moment $(\mathrm{Cl})$.

26-And it $(\mathrm{Cr})$ is $(\mathbf{P c c})$ with a very heavy heart $(\mathrm{Cm})$ 27-that $\mathrm{I}(\mathrm{Sy})$ report(Pv) many deaths and injuries $(\mathrm{Vb})$ amidst the jubilations yesterday $(\mathrm{Cl})$. 28-We (A) send $(\mathbf{P v})$ our sincere condolences $(\mathrm{Vb})$ to the families and friends of those $(\mathrm{Cl})$ 29-who(A) lost $(\mathbf{P m})$ their lives $(\mathrm{G})$; 30-and wish(Pme) speedy recovery $(\mathrm{Ph})$ to those $(\mathrm{Cl})$ 31-who suffered(Pb) injuries(Bh). 32-I(S) appeal(Pv) to all our supporters(Rv) [[to celebrate(Pb) this victory $(\mathrm{Bh})$ with prayers and reflection instead of wild jubilation(Ca)]].

33-May the souls (Be) [[of those who(A) died (Pm)]] rest(Pb) in peace $(\mathrm{Cl})$. 34-Let us(A) take(Pm) a moment of silence $(\mathrm{G})[[$ to honour $(\mathbf{P b})$ all of those $(\mathrm{Bh})[[$ whose sacrifices $(\mathrm{A})$ have brought $(\mathbf{P m})$ us $(\mathrm{G})$ to this fine and historic hour $(\mathrm{Cl})]]$ ]]. 35-As the results of the election( $\mathrm{S})$ have shown $(\mathrm{Pb}), 36$-their labour(Cr) has not been(Pcc) 37-and will never be(Pcc) in vain $(\mathrm{Cm})$. 38-Democracy and the rule of law $(\mathrm{G})$ will be re-established(Pm) in the $\operatorname{land}(\mathrm{Cl})$.

39-Let us(S) put(Pme) the past $(\mathrm{Ph})$, especially $(\mathrm{Cm})$ the recent past $(\mathrm{Ph})$, behind us $(\mathrm{Cl})$. 40-We(S) must forget(Pme) our old battles and past grievances(Ph) 41-and learn(Pme) [[to forge ahead(Pme)]]. 42-I(S) assure $(\mathbf{P v})$ you $(\mathrm{Rv}) 43$-that our government $(\mathrm{T})$ is( $(\mathbf{P i})$ one $(\mathrm{V})[[\operatorname{that}(\mathrm{Bh})$ will listen to $(\mathbf{P b}) / /$ and embrace $(\mathbf{P b})$ all]].

44-I(Sy) pledge(Pv) myself and our in-coming administration(Rv) to just and principled governance $(\mathrm{Cl})$. 45-There shall be(Pe) no bias against or favouritism for any Nigerian based on ethnicity, religion, region, gender or social status(X). 46-I(Sy) pledge(Pv) myself and the government $(\mathrm{Rv})$ to the rule of law $(\mathrm{Cl})$, 47-in which none $(\mathrm{Cr})$ shall be(Pcc) so above the law $(\mathrm{Cl})[[$ that they $(\mathrm{S})$ are not subject to(Pme) its dictates(Ph)]], 48-and none $(\mathrm{Cr})$ shall be $(\mathbf{P i})$ so below it $(\mathrm{Cl})[[$ that they $(\mathrm{S})$ are not availed(Pme) of its protection $(\mathrm{Cl})]]$.

49-You(A) shall be able to go(Pm) to bed(Cl) 50-knowing(Pme) [[that you(Cr) are(Pi) safe(At)//and that your constitutional rights $(\mathrm{Cr})$ remain $(\mathrm{Pcc})$ in safe hands $(\mathrm{Cl})]](\mathrm{Ph})$. 51-You $(\mathrm{Sy})$ shall be able to voice $(\mathrm{Pv})$ your opinion $(\mathrm{Vb})$ without fear of reprisal or victimization $(\mathrm{Cm})$. 52-My love and concern for this nation and [[what $(\mathrm{Ph})$ I (S)desire(Pme) for it $]$ (S) extends(Pme) to all, even to those(Cl) [[who(S) do not like(Pme) us or our politics $(\mathrm{Ph})]$ ]. 53-You(T) are(Pi) all my people(V) 54-and $\mathrm{I}(\mathrm{Be})$ shall treat $(\mathrm{Pb})$ everyone of you as my own(Bh). 55-I(A) shall work (Pm) for those $(\mathrm{Cl})$ 56-who(A) voted(Pm) for me(Cl) 57-as well as those who(A) $\operatorname{voted}(\mathbf{P m})$ against me $(\mathrm{Cl})$ 58-and even for those who(A) did not vote(Pm) at all $(\mathrm{Cm})$. 59-We(Bh) all live(Pb) under one name as one nation $(\mathrm{Cm})$ : $\mathbf{6 0}$-we $(\mathrm{T}) \operatorname{are}(\mathbf{P i})$ all Nigerians $(\mathrm{V})$.

61-Some unfortunate issues about my eligibility $(\mathrm{Vb})$ have been $\operatorname{raised}(\mathbf{P v})$ during the campaign $(\mathrm{Cl})$. 62- $\mathrm{I}(\mathrm{Sy})$ wish(Pme) [[to state(Pv)]] 63-that through devotion to this nation $(\mathrm{Cm})$, everything(T) [[I(S) have learned(Pme)// and done(Pm)]] has been(Pi)[[ to enable(Pme) me(Ph) [[to make(Pm) the best possible contribution to public life(G)]]]](V). 64- If $\mathrm{I}(\mathrm{Cr})$ had judged myself(Pi) incapable(At) [[of governing(Pme)]] 65- $\mathrm{I}(\mathrm{S})$ would never have sought $(\mathrm{Pme})[[$ to impose $(\mathrm{Pb})$ myself($(\mathrm{Bh})$ on it $(\mathrm{Cl})]]$. 66- $\mathrm{I}(\mathrm{A})$ have served(Pm) in various capacities $(\mathrm{Cl})$ 67-and have always put $(\mathrm{Pm})$ in my best $(\mathrm{Cm})$.

68-But despite the rancour of the elections $(\mathrm{Ca}), \mathrm{I}(\mathrm{S})$ extend(Pme) a hand of friendship and conciliation $(\mathrm{Ph})$ to President Jonathan and his team $(\mathrm{Cl})$. 69-I(S) hereby wish(Pme) [[to state(Pv)]] 70-that $\mathrm{I}(\mathrm{S})$ harbor(Pme) no ill will $(\mathrm{Ph})$ against anyone $(\mathrm{Cl})$. 
71-Let me(Sy) state(Pv) clearly $(\mathrm{Cm})$ 72-that President Jonathan $(\mathrm{S})$ has nothing to fear(Pme) from me $(\mathrm{Cl})$. 73-Although we(S) may not agree on(Pme) the methods(Ph) [[of governing(Pme) the nation $(\mathrm{Ph})]]$, 74-he(T) is $(\mathbf{P i})$ a great Nigerian and still our president $(\mathrm{V})$. 75-He(S) deserves(Pme) our support and permanent $\operatorname{respect}(\mathrm{Ph})$ by virtue of the office $(\mathrm{Cm})[[\mathrm{he}(\mathrm{A})$ has held(Pm) $]]$.

76-This $(\mathrm{T})$ is $(\mathbf{P i})$ 77-[how an honourable nation( $\mathrm{Be})$ treats $(\mathbf{P b})$ its servants(Bh)](V) 78-and conducts(Pme) its affairs $(\mathrm{Ph})$; 79-and this(T) is(Pi) 80-how(At) Nigeria(Cr) should be(Pi). 81- $\mathrm{I}(\mathrm{Bh})$ look forward(Pme) $[[$ to meeting with(Pb) President Jonathan $(\mathrm{Ph})$ in the days $(\mathrm{Cm})[[$ to $\operatorname{come}(\mathbf{P m}) / /$ to discuss $(\mathbf{P v})]]$ 82-how our teams $(\mathrm{A})$ can make(Pm) the transition of $\operatorname{administrations}(\mathrm{G})$ as efficient as possible $(\mathrm{Cm})$.

83-Here, I (S)want(Pme) [[to thank(Pv) my party(Vb) [[for $\operatorname{selecting}(\mathbf{P m})$ me $(\mathrm{G})$ as its candidate $(\mathrm{Cl})]]$. 84-I(Sy) thank(Pv) our party leaders and members $(\mathrm{Rv})$ for the steadfast contributions $(\mathrm{Cc})[[\operatorname{they}(\mathrm{S})$ made(Pme) [[to bring(Pm) our dream to fruition $(\mathrm{G})]]]]$. 85-I(Sy) thank(Pv) INEC, the police and all other government $\operatorname{agencies}(\mathrm{Rv})$ [ [for performing(Pm) their $\operatorname{tasks}(\mathrm{G})$ in a proper manner $(\mathrm{Cm}) / /$ and for refusing $(\mathbf{P m e})[[$ to be induced(Pme) [[to undermine(Pm) the election and the democratic process $(\mathrm{G})]]]]$.

86-I(S) also wish(Pme)[[ to thank(Pv)]] religious Leaders, traditional leaders, the media, labour unions, Civil Society organisations, organised private sector, youths and students $(\mathrm{Rv})$ for their roles in this election $(\mathrm{Cc})$.

87-I(Sy)give special(Pv) thanks( $(\mathrm{Vb})$ to President Obama and his timely intervention and $\operatorname{support}(\mathrm{Cl})$ [[for peaceful and credible elections in Nigeria(Cc)// and for sending(Pm) Secretary John Kerry and other United States officials $(\mathrm{G})$. 88-The European Union - especially the United Kingdom, France, Germany and other nations $(\mathrm{Rv})$ [[that(A) were actively involved(Pm) [[in ensuring(Pme) the success of this election(Ph)]]]] are equally $(\mathrm{Cm})$ appreciated(Pv). 89-My sincere thanks( $\mathrm{Vb})$ to the United Nations Secretary General $\mathrm{Mr} \mathrm{Ban}-\mathrm{Ki}$ Moon $(\mathrm{Cl})$. 90-The Commonwealth, China, India and other Asian and Gulf states(Rv) are also hereby(Cl) appreciated(Pv).

91-Finally our brothers in the African Union and ECOWAS(Bh) have truly and clearly $(\mathrm{Cm}) \mathbf{s h o w n}(\mathbf{P b}) \mathbf{9 2}$-and demonstrate(Pb) their commitment to our democratisation process(Bh). 93-Former Presidents John Kuffour, Amos Sawyer, Bakili Muluzi and his team $(\mathrm{Rv})$ are well appreciated(Pv). 94-I(Sy) must also add(Pv) my appreciation $(\mathrm{Vb})$ for the role played by civil societies, national and International observers, other world leaders [[in ensuring(Pme) [[that Nigeria(A) holds(Pm) free and fair elections $(\mathrm{G})]]$.

95-I(Sy) assure(Pv) all foreign governments( $\mathrm{Vb})$ 96-that Nigeria(T) will become(Pi) a more forceful and constructive player(V) in the global fight against terrorism and in other matters of collective concern, such as the fight against drugs, climate change, financial fraud, communicable diseases and other issues requiring global response(Ca). 97-I (S)want(Pme)[[ to assure(Pv)]] our fellow African nations(Ph) 98-that Nigeria(T) will now stand(Pi) as a more constructive partner(V) [[in advancing(Pme) the matters of concern(Ph) to our continent $(\mathrm{Cl})$, particularly with regard to economic development and eradication of poverty $(\mathrm{Cc})]]$.

99-Former head of state and president Chief Olusegun Obasanjo, General Yakubu Gowon, Alh. Shehu Shagari, General Ibrahim Babangida, Chief Ernest Shonekan and General Abdulsalami Abubakar(S) deserve(Pme) commendations $(\mathrm{Ph})$ for their statesmanship and words of caution and counsel for peace during the tense moments of this electoral period $(\mathrm{Cc})$.

100-Most of all, I (Sy) thank(Pv) the people of Nigeria(Ph) [[for reposing(Pme) their confidence $(\mathrm{Ph})$ in me at this trying moment $(\mathrm{Cl})$. 101-Our nation $(\mathrm{A})$ wrestles $(\mathbf{P m})$ many challenges $(\mathrm{G})[[$ including(Pm) insecurity, corruption, economic decline $(\mathrm{G})$. 102-I(Sy) pledge(Pv) [[to give(Pm)]] you(Rv) my best $(\mathrm{G})[[$ in tackling(Pme) these problems $(\mathrm{Ph})]]$.

103-The good people of Nigeria, your obligation(A) does not end(Pm) [[with casting(Pm) your ballot(G)]]. 104- $\mathrm{I}(\mathrm{Be})$ seek(Pb) your voice and input(Bh) 105-as we tackle(Pme) these problems $(\mathrm{Ph})$. 106-This $(\mathrm{T})$ will not be(Pi) a government democratic $(\mathrm{V})$ only in form $(\mathrm{Cm})$. 107-It(T) will be(Pi) a government democratic $(\mathrm{V})$ in substance and in $[[$ how it $(\mathrm{A})$ interacts(Pm) with its own people $(\mathrm{Cm})]](\mathrm{Cm})$.

108-No doubt, this nation $(\mathrm{Be})$ has suffered $(\mathrm{Pb})$ greatly $(\mathrm{Cm})$ in the recent past $(\mathrm{Cl})$, 109-and its staying power( $\mathrm{G})$ has been tested(Pm) to its limits $(\mathrm{Cx})$ by crises(A), [[chief among which $(\mathrm{V})$ is(Pi) insurgency of the Boko $\operatorname{Haram}(\mathrm{T})]]$. 110-There is(Pe) no $\operatorname{doubt}(\mathrm{X})$ 111-that [[in $\operatorname{tackling}(\mathbf{P m})$ the insurgency(G)]] we(A) have(Pm) a tough and urgent job(Pd)[[to do(Pm)]]. 112-But $\mathrm{I}(\mathrm{S})$ assure(Pv) you(Ph) 113-that Boko Haram $(\mathrm{S})$ will soon know(Pme) the strength of our collective will and commitment(Ph) $[[$ to $\operatorname{rid}(\mathbf{P m})$ this nation of terror(G),// and bring back $(\mathbf{P m})$ peace and normalcy $(\mathrm{G})$ to all the affected areas $(\mathrm{Cl})]]$. 114-We(A) shall spare(Pm) no effort(G) 115-until we(A) defeat(Pm) terrorism(G). 
116-Furthermore, we(A) shall strongly battle(Pm) another form of evil(G) [[that $(\mathrm{Cr})$ is( $(\mathbf{P i})$ even worse than terrorism(At) - the evil of corruption. 117-Corruption(A) attacks(Pm) 118-and seeks(Pb) [[to destroy(Pm) our national institutions and character $(\mathrm{G})]]$. 119-[[By misdirecting $(\mathbf{P m})$ into selfish hands $(\mathrm{Cl})$ funds $(\mathrm{G})[[$ intended for(Pme) the public purpose(Ph)]]]], corruption(A) $\operatorname{distorts}(\mathbf{P m})$ the economy $(\mathrm{G})$ 120-and worsens(Pm) income inequality $(G)$. 121-It(A) creates $(\mathbf{P m})$ a class of unjustly-enriched people(G).

122-Such an illegal yet powerful force soon(A) comes(Pm)[[ to undermine(Pm) democracy(G) 123-because its conspirators(A) have amassed(Pm) so much money(G) 124-that they(S) believe(Pme) 125-they(A) can buy $(\mathbf{P m})$ government $(\mathrm{G})$. 126-We(A) shall end(Pm) this threat $(\mathrm{G})$ to our economic development and democratic survival $(\mathrm{Cl})$. 127-I $(\mathrm{Sy})$ repeat $(\mathrm{Pv})$ 128-that corruption $(\mathrm{Ph})$ will not be tolerated(Pme) by this administration(S); 129-and it (S)shall no longer be allowed(Pme) [[to $\operatorname{stand}(\mathbf{P m})]$ ] 130-as if it(T) is(Pi) a respected monument $(\mathrm{V})$ in this nation $(\mathrm{Cl})$.

131- $\mathrm{I}(\mathrm{Sy})$ ask $(\mathrm{Pv})$ you( $(\mathrm{Vb}) \quad[[$ to join(Pme) $\mathrm{me}(\mathrm{Ph}) / / \quad$ in resolving(Pme) these $(\mathrm{Ph})$ and the other challenges $[[$ we $(\mathrm{S})$ face $(\mathbf{P b})$. 132-Along the way $(\mathrm{Cl})$, there will be(Pe) victories $(\mathrm{X})$ 133-but there may also be(Pe) setbacks(X). 134-Mistakes(G) will be made(Pm). 135-But we(S) shall never(Cm) take(Pm) you(Ph) for granted(Cc); 136-so, be rest assured(Pme) 137-that our errors( $\mathrm{T})$ will be(Pi) those of compassion and commitment not of wilful neglect and indifference $(\mathrm{V})$.

138-We(S) shall correct(Pme) that $(\mathrm{Ph})[[$ which(A) does not work(Pm)] 139-and improve(Pme) that $(\mathrm{Ph})$ [[which(A) does(Pm)]]. 140-We(A) shall not stop(Pm), 141-stand(Pm) 142-or idle(Pm). 143-We(A) shall, if necessary crawl(Pm), 144-walk(Pm) 145-and $\operatorname{run}(\mathbf{P m})$ [ $[$ to do $(\mathbf{P m})$ the $j o b(G)[[\operatorname{you}(\mathrm{A})$ have elected(Pm) us[[ to do(Pm)]]]]]].

146- $\mathrm{I}(\mathrm{S})$ realize(Pme) 147-that the expectation of our people $(\mathrm{Cr})$ today $(\mathrm{Cl})$ is $(\mathrm{Pi})$ as high( $\mathrm{At})$ 148-as their commitment (Cr)[[to change(Pme)]] has been(Pi) strong(At)149- and their belief in us(Cr) unshaken(At)). 150-While we(Sy) pledge(Pv) [[to begin doing(Pm) our best without delay $(\mathrm{Cm})]]$, 151-we(S) would like(Pme) $[[$ to appeal(Pv) to them [[to appreciate(Pme) the gravity of our situation] $]]]$, 152-so that we $(\mathrm{Cr})$ become(Pi) more realistic(At) in our expectations $(\mathrm{Cl})$. 153-We(A) will govern $(\mathbf{P m})$ for you and in your interests $(\mathrm{Cl})$. 154-Your vote $(G)$ was not wasted(Pm).

155-This $(\mathrm{T})$ is $\operatorname{not}(\mathbf{P i})$ the first time $(\mathrm{V})$ 156-Nigerians $(\mathrm{A})$ have $\operatorname{cast}(\mathbf{P m})$ their votes $(\mathrm{G})$ for us $(\mathrm{Cl})$, 157-and this $(\mathrm{T})$ is not $(\mathbf{P i})$ the first time $(\mathrm{V}) \mathbf{1 5 8}$ - they $(\mathrm{G})$ have been counted $(\mathbf{P m})$; 159-but this $(\mathrm{T})$ is $(\mathbf{P i})$ the first time $(\mathrm{V})$ 160-that the votes $(\mathrm{Ph})$ have been allowed(Pme) $[[$ to $\operatorname{count}(\mathrm{Pv})]]$. 161-With the help of $\mathrm{God}(\mathrm{Ca})$, we(Sy) pledge $(P v)[[$ to do $(P m)$ our utmost $(\mathrm{G})[[$ to bring forth $(\mathrm{Pm})$ the Nigeria $(\mathrm{G})[[\mathrm{you}(\mathrm{S})$ seek $(\mathrm{Pb})]]]]]]$.162-Thank (Pv) you $(\mathrm{Rv})$ for your patience and attention $(\mathrm{Cc})$.

\section{Copyrights}

Copyright for this article is retained by the author(s), with first publication rights granted to the journal.

This is an open-access article distributed under the terms and conditions of the Creative Commons Attribution license (http://creativecommons.org/licenses/by/3.0/). 